\title{
The Effect of COVID-19 Pandemic on Consumer Emotions and Purchasing Behavior: A Cluster Analysis in Indonesia
}

\author{
Dwinita Laksmidewi ${ }^{*}$, Reinandus Aditya Gunawan ${ }^{1}$
}

\author{
${ }^{1}$ Faculty of Economics and Business, Universitas Katolik Indonesia Atma Jaya, Jakarta, Indonesia \\ *Corresponding author. Email: dwinita.laksmi@atmajaya.ac.id
}

\begin{abstract}
During the COVID-19 pandemic, consumers experience emotions of fear and anxiety. Consumers' emotions have an impact on consumer behavior so that grouping consumers during this pandemic will be useful for determining marketing strategies and tactics that are suitable with them. This study aimed to make consumer psychographic segmentation, based on the negative emotions of consumers towards the pandemic, lifestyle, and purchasing behavior. Negative emotions are focused on fear and anxiety. This study used a survey method to consumers in various cities in Indonesia. To categorize the consumers, we used the K-Means Cluster analysis. The results of this study indicate that three groups were significantly different from each other. The first group, persistent consumers as we call them, are those who have a high fear of the impact of COVID-19, but they can exercise self-control in terms of shopping. The second group, impressionable consumers, are those who feel fear and anxious the most, who are affected by the purchasing style of others, and shop more often. The third group, unaware consumers, are namely those who are less affected by the pandemic psychologically, who are not anxious by the behavior of other consumers, and shop the same as before the pandemic occurred.
\end{abstract}

Keywords: Fear, anxiety, simplicity lifestyle, purchasing behavior

\section{INTRODUCTION}

Since the first case was found in Indonesia in March 2020 until this month (September 2020), the COVID-19 pandemic has not yet ended. This pandemic certainly has a lot of effect on social behavior [1] as well as consumer behavior [2]. The entire community is currently directed to focus on preventive efforts to prevent the spread of the COVID-19 virus so that the COVID-19 pandemic has an impact on purchasing behavior. In Indonesia, consumers' purchasing behavior is limited by the obligation to maintain physical distance. Restrictive policies from the local government also have limited options for shopping and consumers' fear of the pandemic has changed family shopping patterns.

Many consumers experience the feelings of fear of COVID19. Media coverage is busy talking about the high deathrate due to COVID-19. Discussions with experts, sad stories of families left behind by family members, stories of the suffering from COVID-19 patients, word of mouth, rumors, and bombardment of news in traditional or online media trigger the fear of COVID-19 [3]. Government policies have helped to make consumers increasingly convinced that this virus is very dangerous, deadly, and has a negative impact on social and economic conditions. The fear of COVID-19 is a source of stress that affects a person's psychology. The fear varies in level among individuals [4].
The restrictions on outdoor activities and economic conditions are thought to have an influence on consumers' lifestyle. Reducing material consumption is one aspect of simplifying life. However, social and institutional cultural factors have a negative effect on one's ability to simplify life [5].

During a pandemic, unusual consumer behavior such as product hoarding also occurs. A research result shows that frequent exposure to COVID-19 information does not lead to unusual levels of behavior. However, the exposure to this information increases health anxiety [6]. In the study, it was shown that the behavior of people making unusual purchases during COVID-19 was to prepare themselves for isolation and quarantine [6]. A study in Malaysia shows that shopping experience and fear of missing out influence consumers' shopping behavior during the pandemic, of which media coverage becomes a contributing factor [7]. This study aimed to make consumers' psychographic segmentation, based on the negative emotions of consumers towards the pandemic, lifestyle, and shopping behavior. Negative emotions are focused on fear and anxiety. Considering the situation during this pandemic in which consumers find it difficult to leave their house and concerns about health and social problems, we were interested in 
examining whether consumers prioritize simplicity lifestyle in their current life.

\section{LITERATURE BACKGROUND}

\subsection{Consumers' Negative Emotions}

Fear is defined as negative emotions, which are often caused by threats [8]. These threats include future dangers and emotional pain consequences [8]. In the current pandemic situation, the threat is the suffering and death due to the COVID-19 virus, both to oneself and to family members. Because it influences behavior, fear appeal is widely used in marketing to prohibit consumers from doing something bad and directing consumers towards something good. According to Huang, [3] negative emotions due to COVID19 include anger, annoyance, anxiety, depression, disgust, fear, frustration, sadness, hatred, hopelessness, loneliness, panic, regret, and shock. Although fear and anxiety are negative emotions, not all negative emotions are bad; for example, fear and worry can get people to take precautions [3]. Rational anxiety is a situation-appropriate and beneficial level of anxiety that encourages prevention efforts, thus keeps people safe [3]. Irrational anxiety is the anxiety that leads to misestimation of probabilities about risks. For example, someone may refuse to wear a mask, because he is worried that he will not be able to breathe. In buying behavior, consumers see other consumers buying a lot and become irrationally anxious so that they will buy more than they need.

\subsection{Simplicity Lifestyle}

Simplicity lifestyle is described as a lifestyle with low consumption, responsibility for ecology, and selfsufficiency [9]. It is defined as the extent to which a person chooses the desired lifestyle to maximize the direct control over daily activities and minimize the consumption and dependence [9]. According to Shama and Wisenblit [9], simplicity lifestyle includes simplicity material, namely low consumption, buying only what is needed, and not buying excessively. Ecological awareness is a principle that humans and the environment are interdependent so that humans must be ecologically responsible. Human scale means being more concerned with product efficiency, such as choosing a small product. Personal growth emphasizes spiritual and psychological growth rather than economic ability.

Simplicity lifestyle is classified into several groups. The first group of simplifications are the people who have chosen to make small changes in their lives [5]. Their consumption is reduced, but inconsistent and limited in scope. The simplification here is done in response to the hasty and sometimes unsatisfactory lifestyle which is associated with modern society. The second group is strong simplifications. This group is made up of a number of people who may have left successful, high-paying careers, and be full of stress to lead lives on significantly reduced incomes. People with the most noble, holistic simplification adapt their entire life to pursue a simple life and motivated for the environment [5]. These different consumers' characteristics then influence how they respond to marketing stimuli [10]. So, for the marketing to be successful, it needs an understanding of the effects of consumers' emotions and lifestyles.

\section{METHOD}

We surveyed 305 respondents in several cities in Indonesia, consisting of Jakarta (119), Bogor (13), Tangerang (36), Depok (12), Bekasi (24), Bandung (26), Semarang (10), Surabaya (18), Bali (8), Palembang (11), Medan (7), Lampung (9), and Yogyakarta (12). Respondents' description is provided in Table 1. The fear of COVID-19 items adapted from Dymecka, Gerymski, and MachnikCzerwik [4] consist of 6 items $(\alpha=0,851)$. Simplicity lifestyle measurement includes 6 items $(\alpha=0,645)$ adapted from Shama and Wisenblit [9].

\section{Table 1 Respondents}

\begin{tabular}{|c|c|c|}
\hline & & Frequency \\
\hline \multirow[t]{2}{*}{ Gender } & Male & 133 \\
\hline & Female & 172 \\
\hline \multirow{5}{*}{$\begin{array}{l}\text { Monthly income } \\
\text { (Rp million) }\end{array}$} & $<5$ & 101 \\
\hline & $5-10$ & 105 \\
\hline & $11-15$ & 30 \\
\hline & $16-20$ & 16 \\
\hline & $>20$ & 53 \\
\hline \multirow[t]{5}{*}{ Education } & Diploma & 24 \\
\hline & Undergraduate & 155 \\
\hline & Magister & 68 \\
\hline & Doctoral & 10 \\
\hline & Highschool & 48 \\
\hline \multirow[t]{5}{*}{ Work location } & Work from home & 87 \\
\hline & Work from office & 48 \\
\hline & Mixed WFH- & \\
\hline & WFO & 133 \\
\hline & Not working & 57 \\
\hline \multirow{2}{*}{$\begin{array}{l}\text { Family infected of } \\
\text { Covid-19 }\end{array}$} & Exist & 1 \\
\hline & Not exist & 304 \\
\hline \multirow{6}{*}{$\begin{array}{l}\text { Number of family } \\
\text { members }\end{array}$} & 1 & 12 \\
\hline & 2 & 22 \\
\hline & 3 & 46 \\
\hline & 4 & 117 \\
\hline & 5 & 78 \\
\hline & $>5$ & 30 \\
\hline
\end{tabular}


Anxiety consists of 4 items $(\alpha=0,789)$ adapted from Kaur, Kunasegaran, Singh, Salome, and Sandhu [7]. We have developed 6 purchasing behavior items from various sources with $\alpha=0,654$. To classify consumers based on fear, anxiety, simplicity lifestyle, and purchasing behavior, we used K-means cluster analysis.

\section{RESULT AND DISCUSSION}

The results show that all the variables of fear $(F=80.735$ $p=0.000)$, anxiety $(F=189.661 p=0.000)$, lifestyle simplicity $(F=78.676 p=0.000)$ and purchasing behavior $(F=45.826$ $p=0.000$ ) are significant in forming the clusters (Table 2). This means that among the three clusters formed, there are differences in their feelings of fear of a pandemic, anxiety about what other people are doing, as well as consumers' spending reactions to health products, food, and others during the pandemic. Likewise, the principle of lifestyle simplicity significantly builds clusters. Cluster 1 consists of 124 respondents, Cluster 2 consists of 97 respondents, and 84 respondents are included in Cluster 3 (Table 3).

Table 2 ANOVA

\begin{tabular}{lrrrrrr}
\hline & $\begin{array}{c}\text { Cluster } \\
\text { Mean } \\
\end{array}$ & \multicolumn{2}{c}{$\begin{array}{c}\text { Error } \\
\text { Mean }\end{array}$} & & & \\
& Square & df & Square & df & \multicolumn{1}{c}{ F } & Sig. \\
\hline Z-score (Fear) & 52.956 & 2 & .656 & 302 & 80.735 & .000 \\
Z-score (Anxiety) & 84.625 & 2 & .446 & 302 & 189.661 & .000 \\
Z-score & 52.068 & 2 & .662 & 302 & 78.676 & .000 \\
(Simplicity) & 35.389 & 2 & .772 & 302 & 45.826 & .000 \\
Z-score (Purchase) & 3500 \\
\hline
\end{tabular}

\subsection{Cluster Descriptions}

In the following, we describe each cluster and give the cluster a name according to its characteristics.

Table 3. The Number of Cases in Each Cluster

\begin{tabular}{lrr}
\hline Cluster & 1 & 124.000 \\
& 2 & 97.000 \\
& 3 & 84.000 \\
Valid & & 305.000 \\
Missing & & .000 \\
\hline
\end{tabular}

\subsubsection{Cluster 1: Persistent Consumers}

The number of members of this cluster is the largest of all clusters (124 people out of 305). Consumers who are included in this cluster have a high fear of COVID-19 ( $M$ $=5.0457$, Table 4). Their fear level is higher than average, but still lower than that in Cluster 2 (Figure 1). Consumers in Cluster 1 fear losing their lives due to coronavirus infection, fear of serious health complications from coronavirus infection, fear of having to be hospitalized for coronavirus infection, fear of being isolated from family and friends, fear of losing their jobs and income, and fear of losing someone close because of the pandemic. They are not anxious about seeing other people's buying patterns, not watching others shop, and not afraid of other consumers' supplies $(M=2.5585)$. Compared to the other two clusters, consumers in this cluster have the lowest simplicity lifestyle $(M=4,2970)$. Compared to before the pandemic, consumers in Cluster 1 shop online more frequently, buy health products more, and use non-cash payments more often (Table 5).

Overally, it can be described that consumers in this cluster are afraid of COVID-19, but they are not worried about shopping for their needs during the pandemic and not affected by the behavior of other consumers. They are not consumers with a simple lifestyle, because they shop online more often, especially for health needs. We name this cluster Persistent Consumers, who care about the pandemic, but can still control themselves.

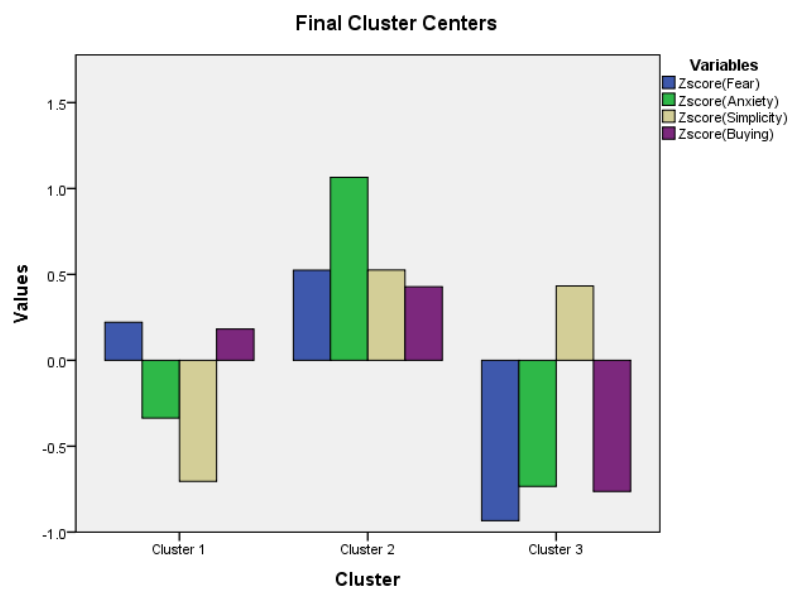

Figure 1 Comparison Among Clusters

\subsubsection{Cluster 2: Impressionable Consumers}

Consumers in this cluster are more afraid of COVID-19 than those in other clusters $(M=5.3488)$. They are also anxious when other consumers buy and are affected by the buying patterns of others $(M=3.9381)$. Even though they have the simplest lifestyle $(M=4.9931)$, consumers in this cluster shop most frequently than those in other clusters due to the fear and anxiety. Besides shopping for the health products more often, they also shop for food more often. Since the pandemic, shopping is more often done online, while offline shopping is less frequent. We call this cluster Impressionable Consumers; they are sensitive to the pandemic situation. The pandemic has made them afraid and anxious, and this has led to their aggressive shopping behavior. 
Table 4 Mean Comparison Among Clusters

\begin{tabular}{|c|c|c|c|c|c|}
\hline & \multicolumn{3}{|c|}{ Cluster Mean (SD) } & \multirow[t]{2}{*}{$F$} & \multirow[t]{2}{*}{$p$} \\
\hline & $\begin{array}{c}1 \\
n=124\end{array}$ & $\begin{array}{c}2 \\
\mathrm{n}=97\end{array}$ & $\begin{array}{c}3 \\
n=84\end{array}$ & & \\
\hline Fear & $\begin{array}{c}5.0457 \\
(.64334)\end{array}$ & $\begin{array}{c}5.3488 \\
(.53147)\end{array}$ & $\begin{array}{c}3.8909 \\
(1.20310)\end{array}$ & 80.735 & 0.000 \\
\hline Anxiety & $\begin{array}{c}2.5585 \\
(.61577)\end{array}$ & $\begin{array}{c}3.9381 \\
(.70066)\end{array}$ & $\begin{array}{c}2.1667 \\
(.66692)\end{array}$ & 189.661 & 0.000 \\
\hline Simplicity Lifestyle & $\begin{array}{c}4.2970 \\
(.44659)\end{array}$ & $\begin{array}{c}4.9931 \\
(.04773)\end{array}$ & $\begin{array}{c}4.9405 \\
(.46830)\end{array}$ & 78.676 & 0.000 \\
\hline $\begin{array}{l}\text { Purchasing } \\
\text { Behavior }\end{array}$ & $\begin{array}{c}3.7030 \\
(.63990)\end{array}$ & $\begin{array}{c}3.8969 \\
(.65900)\end{array}$ & $\begin{array}{c}2.9583 \\
(.79737)\end{array}$ & 45.826 & 0.000 \\
\hline
\end{tabular}

Table 5 Purchasing Behavior

\begin{tabular}{|c|c|c|c|c|c|}
\hline & \multicolumn{3}{|c|}{ Cluster } & \multirow[t]{2}{*}{$F$} & \multirow[t]{2}{*}{$p$} \\
\hline & 1 & 2 & 3 & & \\
\hline Health product shopping & 4.03 & 4.30 & 3.13 & 20.998 & 0.000 \\
\hline Food shopping & 3.74 & 4.03 & 2.54 & 37.858 & 0.000 \\
\hline Online shopping & 4.22 & 4.16 & 3.11 & 19.500 & 0.000 \\
\hline Offline shopping & 2.85 & 3.28 & 2.85 & 3.987 & 0.020 \\
\hline $\begin{array}{l}\text { Buying things other than } \\
\text { food and medicine (for } \\
\text { example, clothes) }\end{array}$ & 2.67 & 2.91 & 2.10 & 10.750 & 0.000 \\
\hline $\begin{array}{l}\text { Using payment without } \\
\text { physical contact }\end{array}$ & 4.07 & 4.07 & 4.04 & 10.518 & 0.000 \\
\hline
\end{tabular}

\subsubsection{Cluster 3: Unaware Consumers}

The number of members in this cluster is the smallest. Consumers in this cluster are least fear of COVID-19 (M =3.8909). They are also least anxious about buying necessities, are not influenced by other consumers, and do not care about other consumers stocking goods $(\mathrm{M}=2.1667)$. Compared to before the pandemic, they do not spend more often on health and food products. Online shopping is the same as it was before the pandemic. We call this cluster Unaware Consumers, because they have little fear of the impact of COVID-19, are not anxious, and their shopping patterns are no different than they were before the pandemic.

Even though the three clusters have different lifestyles, consumers in all clusters show almost the same level of simplicity which is moderate. The pressure of pandemic conditions does not make consumers have very simple lifestyles.

\section{CONCLUSION}

The COVID-19 pandemic has an impact on consumer behavior so that grouping consumers during this pandemic will be useful for determining marketing strategies. This study shows that there are three different groups of consumers based on fear and anxiety emotion, simplicity lifestyle, and shopping behavior. The first group, Persistent Consumers as we call them, are those who have high fear of the impact of COVID-19 on their health, beloved ones, and jobs, but they can still exercise self-control in terms of shopping. The second group, Impressionable Consumers, are those who are most affected psychologically by the impact of COVID-19 on their lives, feel the most fear and anxious, are affected by the purchasing style of other consumers, and as a result, shop more often. Finally, the third group, Unaware Consumers, are those who are less affected by the pandemic psychologically, not anxious by the behavior of other consumers, and shop the same as they did before the pandemic. This study contains weaknesses, namely the number of samples and the distribution of survey locations. However, this research can be continued and provide marketers with an overview of current consumers' grouping based on emotions so that the tactics applied to the target market will be more appropriate.

\section{ACKNOWLEDGMENT}

This work was supported by research grant from The Indonesia Ministry of Research and Technology, 2020. 


\section{REFERENCES}

[1] Ling, G. H. T \& Ho, C. MC (2020). Effects of the Coronavirus (COVID-19) Pandemic on Social Behaviours: From a Social Dilemma Perspective. Technium Social Sciences Journal, 7, 312-320

[2] Zwanka, R. J., \& Buff, C. (2020). COVID-19 Generation: A Conceptual Framework of the Consumer Behavioral Shifts to Be Caused by the COVID-19 Pandemic. Journal of International Consumer Marketing, $0(0), 1-10$. https://doi.org/10.1080/08961530.2020.1771646

[3] Huang, P. H. (2020). Pandemic Emotions: The Good, the Bad, and the Unconscious - Implications for Public Health, Financial Economics, Law, and Leadership. Colorado Law, 20. https://papers.ssrn.com/sol3/Papers.cfm?abstract_id=35 75101

[4] Dymecka, J., Gerymski, R., Machnik, A., \& Machnik-czerwik, A. (2020). Sense of coherence \& fear of covid-19.

[5] McGouran, C., \& Prothero, A. (2016). Enacted voluntary simplicity - exploring the consequences of requesting consumers to intentionally consume less. European Journal of Marketing, 50(1-2), 189-212. https://doi.org/10.1108/EJM-09-2013-0521

[6] Laato, S., Islam, A. K. M. N., Farooq, A., \& Dhir, A. (2020). Unusual purchasing behavior during the early stages of the COVID-19 pandemic: The stimulusorganism-response approach. Journal of Retailing and Consumer Services, 57(July), 102224. https://doi.org/10.1016/j.jretconser.2020.102224

[7] Kaur, K., Kunasegaran, M., Singh, J., Salome, S., \& Sandhu, sukjeet K. (2020). Impact of the First Phase of Movement Control Order during the COVID-19 pandemic in Malaysia on purchasing behavior of Malaysian Consumers. Research Journal of Humanities and Social Sciences, 2(S), 131-144.

[8] Dedeoglu A.O., Ventura K. (2017) Consumer Responses to Swine Flu (H1N1) Threat and Fear Arousing Communications: The Case of Turkey. In: Campbell C.L. (eds) The Customer is NOT Always Right? Marketing Orientationsin a Dynamic Business World. Developments in Marketing Science:

Proceedings of the Academy of Marketing Science. Springer, Cham. https://doi.org/10.1007/978-3-31950008-9_66
[9] Shama, A., \& Wisenblit, J. (1984). Values of voluntary simplicity: Lifestyle and motivation. Psychological Reports, 55(1), 231-240. https://doi.org/10.2466/pr0.1984.55.1.231

[10] Laksmidewi, D., Susianto, H., \& Afiff, A. Z. (2017). The effect of hero archetype in advertising on perceived product efficacy. Indian Journal of Marketing, 47(5), 21-35. https://doi.org/10.17010/ijom/2017/v47/15/114234 